\title{
Serologic and Genomic Relatedness of Group VIII and Group XVII Spiroplasmas and Subdivision of Spiroplasma Group VIII into Subgroups
}

\author{
G. E. GASPARICH,${ }^{1 *}$ C. SAILLARD,${ }^{2}$ E. A. CLARK,${ }^{1}$ M. KONAI,${ }^{1}$ F. E. FRENCH,${ }^{3}$ J. G. TULLY,${ }^{4}$
} K. J. HACKETT, ${ }^{1}$ AND R. F. WHITCOMB ${ }^{1}$

Insect Biocontrol Laboratory, Plant Sciences Institute, Agricultural Research Service, U.S. Department of Agriculture, Beltsville, Maryland 20705'; Laboratoire de Cellulaire et Moléculaire Biologie, Institut de la Recherche Scientifique, 33883 Villenave d'Ornon, France ${ }^{2}$; Department of Biology, Georgia Southern University, Statesboro, Georgia 304603; and Mycoplasma Section, Frederick Cancer Research Center, National Institute of Allergy and Infectious Diseases, Frederick, Maryland $21702^{4}$

\begin{abstract}
Spiroplasmas are currently classified in a group system. Criteria for separation of the twenty-four currently designated groups include serologic relatedness, polyacrylamide gel electrophoretic patterns of proteins, guanine-plus-cytosine base ratios, and, in some cases, DNA-DNA homology. The analysis of DNA-DNA homology and serologic data from a large array of strains recently discovered in dipteran insects reveals that group VII strain EA-1 from a syrphid fly, strain TAAS-1 from a horse fly, and group XVII strain DF-1 from a deer fly belong to a large complex (supergroup) of strains with various degrees of interrelatedness. Strains DF-1 and EA-1 share DNA-DNA homology of 33 to $48 \%$ (high-stringency conditions), while strain TAAS-1 shares 42 to $67 \%$ homology with DF-1 and EA-1. The strains had temperature optima of 30 to $37^{\circ} \mathrm{C}$, but the temperature minima and maxima reflected the geographic region of strain origin. These three strains also share $\mathrm{G}+\mathrm{C}$ values of about $30 \mathrm{~mol} \%$, utilize arginine, and tend to grow in culture to very high titers $\left(10^{11}\right.$ cells per $\mathrm{ml})$. The helical cells of these strains are smaller than those of other spiroplasmas and readily pass through filter pores of $220 \mathrm{~nm}$. These data support the taxonomic placement of the biotypes represented by strains EA-1, DF-1, and TAAS-1 into one supergroup, group VIII, with subgroups designated as VIII-1, VIII-2, and VIII-3, respectively. It is proposed that group XVII remain vacant.
\end{abstract}

Prior to or in lieu of being assigned binomial names, new spiroplasmas are currently classified in a group system (24). Criteria for group separation, first developed by Junca and colleagues (17), form the basis for a classification system that now includes twenty-four groups $(14,22)$, one of which (group I) has been subdivided into eight subgroups. The criteria currently used for classification include serological relatedness, polyacrylamide gel electrophoretic patterns of proteins, guanine-plus-cytosine $(\mathrm{G}+\mathrm{C})$ DNA base ratios, and, in some cases, DNA-DNA homology. The results from these tests have been in general agreement. For this reason, DNA-DNA homology studies, which are labor intensive and pose technical difficulties, have not been performed for many of the groups. Instead, designated groups have been termed "serogroups," because they have been largely delineated on the basis of serologic evidence (24).

Originally, it was thought that serogroups would prove to be essentially equivalent to species. However, subsequent experience $(26,28)$ has shown that subgroups, which differ by at least $30 \%$ in stringent DNA-DNA hybridization tests, are more closely equivalent to species, as currently defined (16). Although there was initial reluctance to elevate subgroups to species status, certain group I subgroups of economic or scientific importance were eventually given binomial epithets (e.g., Spiroplasma citri, $S$. melliferum, $S$. kunkelii, $S$. phoeniceum, and $S$. insolitum). Such a taxonomic elevation is possible if the strains meet the criteria set forth by the International Committee on Systematic Bacteriology Subcommittee on the Taxonomy of Mollicutes (15).

On the basis of the group I model (3), subgroups were at

\footnotetext{
* Corresponding author.
}

first thought to be strain clusters with very limited intrataxal serologic variation. This concept, however, was called into question by the study of group XVI spiroplasmas. These organisms have been isolated from cantharid beetles (8), mosquitoes (7), and flowers (6). Originally, two of the strains, CB-1 and CC-1, from different cantharid beetle species were thought to represent distinct groups because no cross-reaction was observed between them by any of three serologic tests (deformation (DF), metabolism inhibition (MI), and growth inhibition). However, the AEF-2 strain from a mosquito in Alabama (21) exhibited substantial crossreactivity with both strains $\mathrm{CB}-1$ and $\mathrm{CC}-1$. This result demonstrates that strains CB- 1 and CC-1 actually represent ends of a spectrum of antigenically related organisms. The group XVI assemblage, which contains, in addition to the cantharid strains, many isolates from mosquitoes in the French Alps, has recently been analyzed by Abalain-Colloc et al. (1) and was found to consist of strains that shared substantial DNA-DNA homology, showed patterns of partial serological cross-reactivity, and had similar or identical $\mathrm{G}+\mathrm{C}$ contents of their DNAs. Homology levels between the serologically distinct CB-1 (subgroup XVI-2) and CC-1 (subgroup XVI-1) strains were of an order that permitted establishment of subgroups. Strain Ar-1357, representative of the strains from the French Alps, proved to be a member of a third genomically distinct cluster (subgroup XVI-3) of strains with considerable intrataxal serologic heterogeneity.

Recently, the discovery $(8,9,13,19)$ of a large array of group VIII-related spiroplasma isolates in dipterous insects, including horse flies and deer flies (Tabanidae), has offered an opportunity for similar analysis. As serologic studies (13) proceeded, strains that cross-reacted significantly with both group VIII strain EA-1 from a syrphid fly and group XVII 
TABLE 1. Serologic cross-reactivity between representative strains of putative group VIII subgroups

\begin{tabular}{|c|c|c|c|c|c|c|c|}
\hline \multirow{3}{*}{ Antigen to strain } & \multirow{3}{*}{ Putative subgroup } & \multicolumn{6}{|c|}{ Cross-reactivity by the test indicated to antiserum of strain: } \\
\hline & & \multicolumn{2}{|c|}{ EA-1 } & \multicolumn{2}{|c|}{ DF-1 } & \multicolumn{2}{|c|}{ TAAS-1 } \\
\hline & & MI & $\mathrm{DF}$ & MI & DF & MI & DF \\
\hline EA-1 & VIII-1 & 13,000 & 2,560 & 162 & $<20$ & 162 & 20 \\
\hline DF-1 & VIII-2 & $<18$ & $<20$ & 39,000 & 5,120 & 486 & 80 \\
\hline TAAS-1 & VIII-3 & 486 & 20 & 54 & 80 & 39,000 & 5,120 \\
\hline
\end{tabular}

strain DF-1 from a deer fly emerged. Comparison of one of these "bridge strains" with strains EA-1 and TAAS-1 resulted in the present study.

As a result of these studies, it is now clear that the correlation between serology and genomic relatedness is imperfect, that some spiroplasma serogroups may turn out to be genomically related to others, and that clusters of related strains that can be designated as subgroups but that nonetheless exhibit substantial serologic heterogeneity may be encountered. In this paper, we report data linking serogroups VIII and XVII and the linkage of these two groups to a third strain, TAAS-1, from a horse fly in western Texas. We further report the results of genomic analyses that indicate that these three strains, by using the concepts developed by Abalain-Colloc et al. with group XVI strains, should be recognized as new subgroups of group VIII.

\section{MATERIALS AND METHODS}

Origin of isolates. Strain EA-1 (ATCC 33826) was isolated in SM-1 medium (23) in July 1980, from the hemolymph of an adult syrphid fly (Eristalis arbustorum [8]) collected in Beltsville, Md. Strain DF-1 (ATCC 43209) was isolated in M1D medium (23) from the gut contents of an adult female deer fly (Chrysops sp.) collected in August 1983, in Beltsville (9). Strain TAAS-1 (ATCC 51123) was isolated from the gut of a horse fly (Tabanus atratus) collected in September 1987, in Big Bend National Park, Tex.

Culture media and cultivation procedures. All strains were maintained in M1D medium (23) by daily passage into fresh media at a ratio of $1: 10$. One-liter cultures used in the DNA-DNA hybridization analyses were grown in BSR medium (23) in which horse serum was replaced with fetal bovine serum.

Morphology. Cultures were routinely monitored by darkfield microscopy. Filtration studies were performed by passing cultures through filters with pore sizes of 450 and $220 \mathrm{~nm}$.

Temperature requirements. Temperature requirements were determined by preparing 10 -fold dilutions of each strain in M1D medium. The diluted cultures were incubated at 5, $10,15,20,25,30,32,37,41$, and $43^{\circ} \mathrm{C}$. Spiroplasma growth was observed by recording indicator change of the medium and/or by microscopic enumeration of helical filaments in the cultures (20). Each series was incubated for 45 days. Doubling times at each temperature were computed by fitting the temperature-time curves to a logistic growth equation (18). Temperature optima and ranges were determined from these data.

Biochemical tests. Tests for glucose fermentation and arginine hydrolysis were performed by previously published procedures (2).

Serologic tests. MI (27) and DF (29) tests were performed by reciprocal serologic comparison of strains EA-1, DF-1 and TAAS-1.
Genomic analysis. Techniques used to extract DNAs and to determine their $\mathrm{G}+\mathrm{C}$ content have been described previously (4). DNA-DNA hybridization analysis was performed by using the protocol of Degorce-Dumas et al. (10). Hybridization was carried out in buffer containing $0.4 \mathrm{M} \mathrm{NaCl}$ and $50 \%$ formamide for $16 \mathrm{~h}$ at either high stringency $\left(40^{\circ} \mathrm{C}\left[12^{\circ} \mathrm{C}\right.\right.$ below the melting temperature]) or low stringency $\left(22^{\circ} \mathrm{C}\right.$ $\left[30^{\circ} \mathrm{C}\right.$ below the melting temperature]). Hybrids were then subjected to $\mathrm{S} 1$ nuclease treatment. In hybridization experiments, tritium-labelled DNAs from strains EA-1, DF-1, and TAAS-1 were used to probe unlabelled DNA from each strain and from controls (salmon sperm, Escherichia coli DHF $\alpha$, and $S$. citri R8A2 DNA).

\section{RESULTS}

Morphology. By dark-field microscopy, a shared distinctive morphology was observed for spiroplasma strains DF-1, EA-1, and TAAS-1. Helical filaments formed by these strains were considerably smaller than those $(8,9)$ of other groups. Cells of all three strains readily passed through 220-nm-pore-size membrane filters. Quantitatively, titrations of several strains and microscopic enumeration suggested that the organisms grew to titers of about $10^{11}$ cells per ml.

Temperature requirements. The temperature range of growth for spiroplasma strain DF-1 was 10 to $32^{\circ} \mathrm{C}$, with optimal growth at $30^{\circ} \mathrm{C}$ (doubling time of $6.4 \mathrm{~h}$ ). Spiroplasma strain EA-1 grew at a range of 10 to $41^{\circ} \mathrm{C}$, with an optimum at $32^{\circ} \mathrm{C}$ (doubling time of $1.0 \mathrm{~h}$ ). The optimal growth temperature for spiroplasma strain TAAS- 1 was found to be $37^{\circ} \mathrm{C}$, with a temperature range $\left(15\right.$ to $\left.41^{\circ} \mathrm{C}\right)$ slightly more restrictive at lower temperatures (no growth at $10^{\circ} \mathrm{C}$ ), and the doubling time was $1.4 \mathrm{~h}$.

Serologic analysis. Strains EA-1, DF-1, and TAAS-1 shared antigenic determinants (Table 1). Although strains EA-1 and DF-1 failed to cross-react reciprocally in DF and MI tests, antisera to strain TAAS-1 cross-reacted weakly with strains EA-1 and DF-1, by the MI test.

Biochemical analysis. All three strains fermented glucose with the production of acid and catabolized arginine with the production of ammonia.

Genomic analysis. (i) Guanine-plus-cytosine content. The $\mathrm{G}+\mathrm{C}$ content of strains EA-1 and DF-1 has been previously determined to be 29 to $30 \mathrm{~mol} \%$ (5). In this study, with strains EA-1 and DF-1 as controls, the G+C content of strain TAAS-1 was found to be $(30 \pm 1) \mathrm{mol} \%$.

(ii) DNA-DNA hybridization. In the three homologous reactions, with labelled and unlabelled DNA from the same strain, experimental (high-stringency) hybridization values were greater than $70 \%$ (Table 2 ). These values were normalized to $100 \%$. Under these conditions, strain DF-1 is $33 \%$ homologous to strain EA-1 and $54 \%$ homologous to strain TAAS-1; homology values for all three controls were $12 \%$ or less. Under the same conditions, strain EA-1 was found to 
TABLE 2. Percent homology between DNA from spiroplasma strains DF-1, EA-1 and TAAS-1

\begin{tabular}{|c|c|c|c|c|c|c|}
\hline \multirow{3}{*}{$\begin{array}{c}\text { Source of } \\
\text { unlabelled DNA }\end{array}$} & \multicolumn{6}{|c|}{$\%$ Homology of tritium-labelled DNA from strain at the temp indicated ${ }^{a}$ : } \\
\hline & \multicolumn{2}{|c|}{ DF-1 } & \multicolumn{2}{|c|}{ EA-1 } & \multicolumn{2}{|c|}{ TAAS-1 } \\
\hline & $40^{\circ} \mathrm{C}$ & $24^{\circ} \mathrm{C}$ & $40^{\circ} \mathrm{C}$ & $24^{\circ} \mathrm{C}$ & $40^{\circ} \mathrm{C}$ & $24^{\circ} \mathrm{C}$ \\
\hline DF-1 & $100(91)$ & $100(79)$ & 48 & 70 & 42 & 64 \\
\hline EA-1 & 33 & 61 & $100(74)$ & $100(80)$ & 67 & 81 \\
\hline TAAS-1 & 54 & 66 & 54 & 93 & $100(70)$ & $100(90)$ \\
\hline S. citri R8A2 & 11 & 24 & 15 & 21 & 15 & 24 \\
\hline E. coli $\mathrm{DH} 5 \alpha$ & 7 & 27 & 14 & 33 & 16 & 23 \\
\hline Salmon sperm & 12 & 31 & 12 & 30 & 14 & 35 \\
\hline
\end{tabular}

${ }^{a}$ All values were normalized to a homologous value, defined as $100 \%$. The values in parentheses were obtained during homologous hybridization experiments.

be $48 \%$ homologous to strain DF-1 and $54 \%$ homologous to strain TAAS-1, while control values were $15 \%$ or less. Finally, strain TAAS- 1 was found to be $42 \%$ homologous to strain DF-1 and $67 \%$ homologous to strain EA-1, while controls had homology values of $16 \%$ or less. As shown in Table 2, hybridization analyses with the low-stringency temperature conditions yielded increased melting temperature values, which were still consistently higher than the values obtained with the controls.

\section{DISCUSSION}

Strains EA-1, DF-1, and TAAS-1 share limited DNADNA homology at a level that is appropriate (1) for the designation of a subgroup (33 to $67 \%$ ). Accordingly, we designate these strains as representatives of subgroups VIII-1, VIII-2, and VIII-3, respectively. The abandonment of the group XVII designation for strain DF-1 leaves this group designation vacant. We propose that it remain vacant, with a permanent notation of the change in group nomenclature for strain DF-1.

The three clusters represented by these strains form a coherent group with several shared properties. These properties include residence in dipterous insects, small size (low number of turns per helix), wide temperature growth ranges, arginine utilization, a $\mathrm{G}+\mathrm{C}$ content of $(29$ to $30 \pm 1) \mathrm{mol} \%$, and certain antigenic determinants. A group of spiroplasma strains in which clusters of strains show 30 to $70 \%$ DNADNA homology with other clusters has recently been referred to as a supergroup (26).

The criteria proposed for subgroups $(15,17)$, based largely on experience with spiroplasma group I, were established on the assumption that a subgroup consists of a rather closely related set of strains, with little relatedness to other subgroups. Unfortunately, this subgroup model has proved to be inapplicable to spiroplasmas in general. Three group I subgroups are plant pathogens, and the other five subgroups represent either rarely collected or geographically distinct strains. For this reason, there was little if any opportunity to observe intergrading characteristics among these subgroups. The model developed by Abalain-Colloc and colleagues (1) for group XVI spiroplasmas appears to be more typical of spiroplasma assemblages.

Although three group VIII clusters have emerged from our studies, the results from serotyping large arrays of isolates from tabanid flies have shown that substantial intracluster variability exists (25). The full extent of this variation is unknown at present.

The subgroups proposed herein have geographical and ecological traits that correlate well with their genomic and serologic differentiation. For example, the low temperature range $\left(10\right.$ to $32^{\circ} \mathrm{C}$ ) of strain $\mathrm{DF}-1$ probably reflects its northern distribution. While the DF-1 strain from Maryland and related isolates from Idaho appear to be associated with the deer fly genus Chrysops, strains of this subgroup have not been isolated from Chrysops spp. in Georgia (11). In contrast, the EA-1 strain was isolated from a syrphid fly in Maryland, with partially related strains obtained from tabanid flies in Georgia. This midlatitudinal U.S. cluster of strains had the widest temperature range. Similarly, the cool-temperature intolerance of strain TAAS-1 may reflect its southern origin. This strain was isolated from a large horse fly, $T$. atratus, in the warm climate along the Rio Grande River in western Texas. Some Georgia horse fly isolates show substantial cross-reactivity with this strain.

Group VIII serovars are among the most common isolates from tabanids in Georgia (12). Preliminary analysis of more that 100 of these isolates (25) suggests that the subgroup classification proposed herein is a reasonable approach to the classification of serovars from tabanids. Furthermore, this approach is concordant with the work of Abalain-Colloc et al. (1) with group XVI spiroplasmas. Analysis of these isolates will test the hypothesis that a supergroup-subgroup classification system (26) can be used to classify large arrays of interrelated spiroplasma serovars. In any event, special precautions must be taken in future serological studies to carefully consider minor cross-reactions between representatives of subgroups that could portend future difficulties in group nomenclature.

\section{REFERENCES}

1. Abalain-Colloc, M.-L., D. L. Williamson, P. Carle, J. H. Abalain, F. Bonnet, J. G. Tully, M. Konai, R. F. Whitcomb, J. M. Bové, and C. Chastel. 1993. Division of group XVI spiroplasmas into subgroups. Int. J. Syst. Bacteriol. 43:342-346.

2. Alluotto, B. B., R. G. Wittler, C. O. Williams, and J. E. Faber. 1970. Standardized bacteriologic techniques for the characterization of Mycoplasma species. Int. J. Syst. Bacteriol. 20:35-58.

3. Bové, J. M., C. Mouches, P. Carle-Junca, J. R. Degorce-Dumas, J. G. Tully, and R. F. Whitcomb. 1983. Spiroplasmas of group I: the Spiroplasma citri cluster. Yale J. Biol. Med. 56:573-582.

4. Carle, P., C. Saillard, and J. M. Bové. 1983. Determination of guanine-plus-cytosine content of DNA. Methods Mycoplasmol. 1:301-308.

5. Carle, P., J. G. Tully, R. F. Whitcomb, and J. M. Bové. 1990. Size of the spiroplasmal genome and guanine plus cytosine content of spiroplasmal DNA. Zentralbl. Bakteriol. 20(Suppl.): 889-892.

6. Chastel, C., B. Gilot, F. Le Goff, B. Devau, G. Kerdraraon, I. Humphrey-Smith, R. Gruffaz, and A.-M. Simitzix-Le Flohic. 1990. New developments in the ecology of mosquito spiroplasmas. Zentralbl. Bakteriol. 20(Suppl.):455-460.

7. Chastel, C., B. Gilot, F. Le Goff, R. Gruffaz, and M.-L. Abalain-Colloc. 1985. Isolement de spiroplasmes en France 
(Savoie, Alpes du Nord) à partir de moustiques du genre Aedes. C.R. Acad. Sci. 300:261-266.

8. Clark, T. B. 1982. Spiroplasmas: diversity of arthropod reservoirs and host-parasite relationships. Science 217:57-59.

9. Clark, T. B., B. V. Peterson, R. F. Whitcomb, R. B. Henegar, K. J. Hackett, and J. G. Tully. 1984. Spiroplasmas in the Tabanidae. Isr. J. Med. Sci. 20:1002-1005.

10. Degorce-Dumas, J. R., B. Ricard, and J. M. Bové. 1983. Hybridization between mycoplasma DNAs. Methods Mycoplasmol. 1:319-326.

11. French, F. E. Unpublished data.

12. French, F. E., and R. F. Whitcomb. Unpublished data.

13. French, F. E., R. F. Whitcomb, J. G. Tully, K. J. Hackett, E. A. Clark, R. B. Henegar, A. G. Wagner, and D. L. Rose. 1990. Tabanid spiroplasmas of the Southeast USA: new groups, and correlation with host life history strategy. Zentralbl. Bakteriol. 20(Suppl.):919-921.

14. Guo, Y. H., T. A. Chen, R. F. Whitcomb, D. L. Rose, J. G. Tully, D. L. Williamson, X. D. Ye, and Y. X. Chen. 1990. Spiroplasma chinense sp. nov. from flowers of Calystegia hederacea in China. Int. J. Syst. Bacteriol. 40:421-425.

15. International Committee on Systematic Bacteriology Subcommittee on the Taxonomy of Mollicutes. 1984. Minutes of the interim meeting, 30 August to 6 September 1982, Tokyo, Japan. Int. J. Syst. Bacteriol. 34:361-365.

16. Johnson, J. L. 1984. Nucleic acids in bacterial classification, p. 8-11. In N. R. Krieg and J. G. Holt (ed.), Bergey's manual of systematic bacteriology, vol. 1. Williams \& Wilkins, Baltimore.

17. Junca, P., C. Saillard, J. Tully, O. Garcia-Jurado, J. R. DegorceDumas, C. Mouches, J. C. Vignault, R. Vogel, R. McCoy, R. Whitcomb, D. Williamson, and J. M. Bové. 1980. Caractérisation du spiroplasma isoles d'insectes et de fleurs de France continentale, de Corse et du Maroc: proposition pour une classification. C.R. Acad. Sci. Ser. D 290:1209-1211.

18. Konai, M., E. A. Clark, and R. F. Whitcomb. 1992. Temperature ranges and optima of spiroplasmas, p. 137. In Proceedings of the 9th International Congress of the International Organization for
Mycoplasmology, Ames, Iowa, 2 to 7 August 1992.

19. Le Goff, F., I. Humphrey-Smith, M. Leclercq, and C. Chastel. 1991. Spiroplasmas from European Tabanidae. Med. Vet. Entomol. 5:143-144.

20. Rodwell, A. W., and R. F. Whitcomb. 1983. Methods for direct and indirect measurement of mycoplasma growth. Methods Mycoplasmol. 1:185-196.

21. Shaikh, A. A., W. E. Johnson, Jr., C. Stevens, and A. Y. Tang. 1987. The isolation of spiroplasmas from mosquitoes in Macon County, Alabama. J. Am. Mosq. Control Assoc. 3:289-295.

22. Tully, J. G., D. L. Rose, E. Clark, P. Carle, J. M. Bové, R. B. Henegar, R. F. Whitcomb, D. E. Colflesh, and D. L. Williamson. 1987. Revised group classification of the genus Spiroplasma (class Mollicutes), with proposed new groups XII to XXIII. Int. J. Syst. Bacteriol. 37:357-364.

23. Whitcomb, R. F. 1983. Culture media for spiroplasmas. Methods Mycoplasmol. 1:147-158.

24. Whitcomb, R. F., J. M. Bové, T. A. Chen, J. G. Tully, and D. L. Williamson. 1987. Proposed criteria for an interim serogroup classification for members of the genus Spiroplasma (class Mollicutes). Int. J. Syst. Bacteriol. 37:82-84.

25. Whitcomb, R. F., and F. E. French. Unpublished data.

26. Whitcomb, R. F., D. L. Williamson, J. M. Bové, J. G. Tully, K. J. Hackett, G. E. Gasparich, and M.-L. Abalain-Colloc. Unpublished data.

27. Williamson, D. L., J. G. Tully, and R. F. Whitcomb. 1979. Serological relationships of spiroplasmas as shown by combined deformation and metabolism inhibition tests. Int. J. Syst. Bacteriol. 29:345-351.

28. Williamson, D. L., J. G. Tully, and R. F. Whitcomb. 1989. The genus Spiroplasma, p. 71-109. In J. G. Tully and R. F. Whitcomb (ed.), The mycoplasmas. Academic Press, Inc., New York.

29. Williamson, D. L., and R. F. Whitcomb. 1983. Special serological tests for spiroplasma identification. Methods Mycoplasmol. 2:249-259. 